\title{
Stability of Droughty Ground of European Russia to the Processes of Desertification
}

\author{
Victoria Georgievna Lazareva and Valentina Aleksandrovna Bananova
}

\author{
Ukhta state technical University, Russia, Republic Komi, \\ Ukhta City, 169300, Pervomayskaya street 13 \\ Kalmyk State University, Russia, Republic Kalmykia, Elista City, 358000, Pushkin Street, 11
}

DOI: http://dx.doi.org/10.13005/bbra/1926

(Received: 15 August 2015; accepted: 12 October 2015)

\begin{abstract}
The article gives the results of long-term researches regarding the processes of desertification of droughty European grounds - Russian Caspian areas. The fact that the authors consider desertification as unification, which leads to degradation of all arid ecosystems components, makes the approach particular. It was determined that the ecodynamic species of vegetation subclass had the largest indicator value enabling to trace sequence of degradation, allocate the criteria of the evaluation, and stages (classes) of desertification. They make the main content of biological conception of desertification developed by the authors. Cartographic materials prove convertibility of this process in the conditions of semiarid zone of European continent under influence of natural and natural-anthropogenic factors.
\end{abstract}

Keywords: desertification, drylands, evaluation criteria, unification, biological concept, degradation, vegetation, indicator, pasture degradation, redesertification.

Until 1977 the term “desertification” was quite rare in research literature.Long-term drought in the Sudan-Sahelian region of Africa forced to raise this issue at the UN (United Nations) level, to create a number of international organizations, and to develop and adopt the Convention to Combat Desertification ${ }^{1}$. Domestic and foreign researchers have made a significant contribution to the study of the problem: N.G. Kharin, B.V. Vinogradov,B.G.Rozanov,H. Dregne; H. Le Houerou; M. Kassas; M.H.Glantz, İ. Tolba et al. Regional studies acquire special importance in combating desertification ${ }^{2-4}$. Modern problems of desertification of Russian droughty grounds were considered in a number of collective monographs ${ }^{5,6}$, etc. The landscapes of the semiarid zone within which the Republic of Kalmykia is

\footnotetext{
* To whom all correspondence should be addressed.
}

located turned especially brittle.The Republic of Kalmykia is located in the extreme south-eastern Europe, borders in the North on Volgograd oblast, in the East - on Astrakhan oblast, in the South - on the Republic of Dagestan, and is bounded by the Caspian Sea. The ecological situation in the region is reflected on the map "Anthropogenic desertification of Kalmyk ASSR”. Its analysis shows that in the late eighties of the twentieth century almost the entire area was covered by desertification, out of which 770 thousand $\mathrm{Ha}$ (10.0\%) were occupied by the open sands. The chernozem pastures with strong and very strong desertification of $75.6 \%$ of the areas corresponded to the zone of ecological disaster. In those years under the conditions of high biogenic and anthropogenic impact, and high climate aridity the anthropogenic desert formed for the first time on the European continent ${ }^{7,18}$.

In order to combat desertification, the scientists developed: "General Scheme to Combat 
Desertification Black Lands and Kizlyar Pastures"8, with the financial support of UNEP "The national program to combat desertification in Kalmykia,", and the Directorate "Agrolesomeliostroy" was created. After the collapse of the USSR, change of arid climate cycle by humid, the situation in the region changed, and the need for new research and the development of the second phase of "General Scheme...." arose.

\section{Research methods}

The United Nations Convention to Combat Desertification defines it “... as a process of land degradation in arid, semi-arid and dry subhumid areas resulting from various factors, including climatic variations and human activities." The current state of arid landscapes is defined by indicators, the criteria of qualitative and quantitative assessment of desertification processes.

At the beginning of the XXI century the major resumptive writings devoted to general methodological problems of desertification appeared $^{10-13}$. In these studies, the variations in climate and as a result, the economic and social risks generated by it and by anthropogenic factors were determined as the most important factor contributing to the degradation.In the International program "Millennium Ecosystem Assessment MEA" the emphasis in definition of desertification was shifted from degradation to a steady decrease in the dryland ecosystems productivity ${ }^{14}$.

Based on the concept and methodology of the study of desertification of FAO / UNEP (United Nations Food and Agriculture Organization / United Nations Environment Programme) of the Institute of Deserts of the Academy of Sciences of Turkmenistan [1.15], the authors of this article have made a number of amendments thereto in relation to purposes and natural features of the study area.In addition, we have developed an environmental concept that allows us to trace the entire course of organic evolution, the natural environment differentiation in natural and anthropogenic conditions of desertification ${ }^{16-18}$. The husbandry practice in arid environments of Kalmykia showed that soil and vegetation are the most comprehensive indicators of the current state of the environment.The weakening of the selfmaintenance ability of communities is observed upon a strong pasture degradation, soil erosion and manmade influences. There is a loss of entire populations over large areas, the heterogeneity of soil and vegetation cover is being reduced, and the mechanisms regulating the phase shift within cycles are disappearing ${ }^{19}$.

The young age of the Russian Caspian Sea territory, its exposure to natural conditions fluctuations, and the increased role of weed and ruderal plants are, apparently, the main components of the fragility and rapid degradation of ecosystems on the sandy plains of Europe.In the event of breakdown, the degradation breaks the rhythm of links and processes. In case of reversible changes, the waves of active development of desertification processes are followed by ecosystems recovery periods, botanical diversity increase. In case of irreversible changes the ecosystems lose the occupied spaces, turning into wastelands.

Therefore, the identified natural and anthropogenic variability of the environment and the relevant adaptation of organisms depending on the degree of degradation make up the main content of the biological concept of desertification developed by us $^{20}$.

The analysis of map documents developed by us confirms this concept. In the years with the highest (1970-1988) and the smallest (19902000) anthropogenic load, the desertification occupied almost the same area - 87.2: $87.9 \%$, but the degree of ecosystems degradation has been dramatically changing. The area occupied by a weak class at the beginning of the XXI century has increased from 8.3 to $70.1 \%$, and on the contrary the area occupied by a strong and very strong class decreased from 47.8 to $11.2 \%$ of transplanted sands from 770.0 to 126.1 thousand ha. This is primarily due to global warming observed in recent decades and to the simultaneous tendency to increase the amount of precipitation, which are most clearly seen in the Caspian region.Here an increase in the mean annual precipitation from $209 \mathrm{~mm}$ to $470 \mathrm{~mm}$, as well as a sharp decline in livestock from 3.5 million to 450 thousand in the period 1990-2007 led to the restoration of plant stand.In steppe communities on brown soils and wind erosion foci this process was particularly active $e^{7,17,18,19}$.

\section{RESULTSAND DISCUSSION}

The study of the processes of desertification made it possible to separate human factors by their origin into two groups: exogenous 
and endogenous. Under the influence of the exogenous factors the soil and vegetation cover is deformed or destroyed; while the groundwater are penetrated and the soil-forming parent rocks are destroyed upon influence of endogenous factors. The first group includes the effects of pasture digression, fires, plowing, and the second - the construction and development of drainage systems, exploration and production of minerals.

Kalmykia is the stock-raising republic, nowadays this is one of the leading regions of the Russian Beef Belt. In this regard, the pasture digression is the main type of anthropogenic desertification. It was first described by G.N. Vysotskyin 1915 and considered by him as an exogenous succession of regressive type occurring upon cattle grazing. We have determined not separate species, but the communities in which they dominate as an indicator of the stages (classes) of pasture digression in different types of ecosystems. Upon digression increase in neighboring communities of the same landscape, the abundance of one or more plant species changes, i.e. the transformation of an ordinary component of the community's into its dominant (or vice versa) occurs. We call this process the "shift unification", and the penetration of new species and their attainment of a dominant position in the community - the "incorporation unification". As a result, if we compare the indicator communities with each other, it turns out that they form a series, whose elements interchange in time.The same sequence of changes can be traced in space: approximation or removal from the digression source. Such indicators contingency in shifts in time and at the same time their alternation in close sequence in space allow to refer the series of pasture digression indicators to environmental one.The prevalence of these environmental and time series makes this process smooth, gradual, difficult to display, and requires detailed profiling. These studies were carried out on the permanent landfills located in different geomorphologic regions of the Caspian Sea. The criteria for assessing the sustainability of phytocenoses developed by us allow tracing the mechanism of landscapes degradation (see Table 1).

The reserve "ChorniyeZemli" is the subject of research for this article. This is the only protected natural complex located in the arid zone of the European continent (121.9 thous. Ha). It was established in 1990. In May 1993 it was included in the World Network of Biosphere Reserves. The main purpose of reserve research is the protection of Kalmyk saiga population; the development of predictive scenarios of ecosystems recovery after prolonged human impact. The landfill is located on the sabulous and sand coastal plain with Baer knolls, and the absolute sea levels range from (-15) to $(-19) \mathrm{m}$ above sea level, the continental development period is 9-11 thous. years. The desert steppes on brown alkaline soils that include Artemisia lerchiana, Festucavalesiaca, Stipasareptana, Agropyron fragile in conjunction with subshrub deserts on alkali soils (Artemisia lerchiana - Camphorosmamonspeliaca), psamophytic and halophytic communities on dispersed sands and salt marshes (Table1) are the background vegetation.

In the eighties of the $\mathrm{XX}$ century the overload of chernozemic pastures with cattle, the tilling of sabulous and sandy soils created the hummock and barchan relief in the territory of future reserve. The degree of degraded lands amounted to $96.2 \%$, with $56.1 \%$ being in a stage of strong and very strong desertification, corresponding to the zone of ecological disaster. Here, on the tops of barchans Calligonumaphyllum was occasionally presented, Leymusracemosus - on the slopes, Artemisia lerchianasabulosa involving Agropyron fragile in interbarchan degradations. The species composition of the communities ranged from 0 to 5-7 species, projective cover - from $0-15 \%{ }^{16}$.

Currently, the chernozemic pastures are the stage for demutational processes, the indicator of which is vegetation. The recent research showed that the plant communities with the dominance of Stipasareptana, Agropyron fragile, Achilleamicrantha, Artemisia lerchianasabulosa are widespread in the vegetation of the reserve in the absence of grazing; the presence of ephemera, ephemeroids and annuals is gradually reduced. The sands overgrowing happens by spots (microgroups), alternating with bare sands, vegetation of interbarchan degradations. Thanks to this from the barchan-hummock the relief is gradually transformed into a pit-and-mount.

The recovery (redesertification) process can be seen in the species composition of the 
communities: Leymusracemosus, Calligonum aphyllum is still dominated on the tops of the barchans, but the floristic composition increased to 10-14 species due to Astragalus longipetalus, Festucabeckeri, Koeleria glauca, Euphorbia seguerana and others. There is the domination on

Table 1. The criteria for assessing the sustainability of phytocenoses upon pasture digression on brown soils of Kalmykia

\begin{tabular}{|c|c|c|c|c|c|}
\hline \multirow{2}{*}{$\begin{array}{l}\text { Criteria } \\
1\end{array}$} & \multirow{2}{*}{$\begin{array}{l}\text { Background } \\
\text { level } \\
2\end{array}$} & \multicolumn{4}{|c|}{ Desertification classes } \\
\hline & & 3 & 4 & 5 & 6 \\
\hline $\begin{array}{l}\text { Economic } \\
\text { state of } \\
\text { communities }\end{array}$ & $\begin{array}{l}\text { Original } \\
\text { vegetation } \\
\text { type }\end{array}$ & Weak & Moderate & Strong & Very strong \\
\hline $\begin{array}{l}\text { Degradation } \\
\text { of the } \\
\text { structure of } \\
\text { zonal } \\
\text { vegetation: } \\
\text { à) } \\
\text { phytocenotic }\end{array}$ & $\begin{array}{l}\text { Hemipsamm } \\
\text { ophytic type } \\
\text { of } \\
\text { desertificated } \\
\text { steppe }\end{array}$ & $\begin{array}{l}\text { Appearance of } \\
\text { fragments of } \\
\text { psammophytic } \\
\text { desert steppes } \\
\text { options }\end{array}$ & $\begin{array}{l}\text { Psammophyticde } \\
\text { sertificated } \\
\text { steppe with } \\
\text { fragments of } \\
\text { hemipsammophyt } \\
\text { ic steppe }\end{array}$ & $\begin{array}{l}\text { Psammophytic } \\
\text { desertificated } \\
\text { steppe with } \\
\text { fragments of } \\
\text { sandy desert }\end{array}$ & $\begin{array}{l}\text { Unvegetated } \\
\text { sandy } \\
\text { deserts } \\
\text { Dispersed } \\
\text { sands }\end{array}$ \\
\hline $\begin{array}{l}\text { b) } \\
\text { ecological }\end{array}$ & $\begin{array}{l}\text { Domination } \\
\text { of xerophytes } \\
\text { with } \\
\text { significant } \\
\text { participation } \\
\text { of second and th } \\
\text { psammophytes }\end{array}$ & $\begin{array}{l}\text { Domination of } \\
\text { third order } \\
\text { xerophytes and } \\
\text { psammophytes, } \\
\text { with the 2nd } \\
\text { hird order }\end{array}$ & $\begin{array}{l}\text { Domination of } \\
\text { third order } \\
\text { psammophytes, } \\
\text { with the } 2 \text { nd } \\
\text { order } \\
\text { order psammophytes } \\
\text { xerophytes }\end{array}$ & $\begin{array}{l}\text { Domination of } \\
\text { second order } \\
\text { psammophytes, } \\
\text { with the } \\
\text { 1st order } \\
\text { psammophytes } \\
\text { psammophytes) }\end{array}$ & $\begin{array}{l}\text { Shifting } \\
\text { sands } \\
\text { overgrowin } \\
\text { g pioneers } \\
\text { (1st order } \\
\text { psammophytes, }\end{array}$ \\
\hline $\begin{array}{l}\text { c)biomorph } \\
\text { ological }\end{array}$ & $\begin{array}{l}\text { Dominance } \\
\text { of } \\
\text { perennial } \\
\text { grasses }\end{array}$ & $\begin{array}{l}\text { Dramatic share } \\
\text { of } \\
\text { dwarf shurbs }\end{array}$ & $\begin{array}{l}\text { The dominant role } \\
\text { of the dwarf } \\
\text { shrubs with a } \\
\text { significant } \\
\text { participation of } \\
\text { annual plants }\end{array}$ & $\begin{array}{l}\text { Dominance of } \\
\text { annual plants, } \\
\text { ephemera, } \\
\text { ephemeroids, } \\
\text { with } \\
\text { psammophilous } \\
\text { shrubs, perennial } \\
\text { grasses }\end{array}$ & $\begin{array}{l}\text { Psammophilo } \\
\text { us } \\
\text { shrubs, } \\
\text { annual } \\
\text { and perennia } \\
\text { l grasses }\end{array}$ \\
\hline $\begin{array}{l}\text { 3. Projective } \\
\text { covering, \% } \\
\text { 4. Yields in }\end{array}$ & $45-35$ & $35-25$ & $25-15$ & $15-5$ & $5-0$ \\
\hline $\begin{array}{l}\% \text { of } \\
\text { potential }\end{array}$ & $100-90$ & 90 & $90-65$ & $65-40$ & less than 25 \\
\hline $\begin{array}{l}\text { 5. Stage of soil- } \\
\text { forming } \\
\text { process } \\
\text { with an indicatio }\end{array}$ & $\begin{array}{l}\text { Brown } \\
\text { sabulous soils } \\
\text { on }\end{array}$ & $\begin{array}{l}\text { Brown sabulous } \\
\text { soils, } \\
\text { degradating }\end{array}$ & $\begin{array}{l}\text { Brown sabulous } \\
\text { and sandy soils, } \\
\text { stripped }\end{array}$ & $\begin{array}{l}\text { Brown sabulous } \\
\text { and sandy soils }\end{array}$ & $\begin{array}{l}\text { Loose and } \\
\text { shifting } \\
\text { sands }\end{array}$ \\
\hline $\begin{array}{l}\text { of the } \\
\text { type of soil }\end{array}$ & & & & & \\
\hline $\begin{array}{l}6 . \\
\text { Microrelief } \\
\text { degradation }\end{array}$ & Plain, hollow & $\begin{array}{l}\text { Plain, slide, with } \\
\text { knobs }\end{array}$ & $\begin{array}{l}\text { Hummock-and- } \\
\text { hollow }\end{array}$ & $\begin{array}{l}\text { Hummock-and- } \\
\text { hollow }\end{array}$ & $\begin{array}{l}\text { Hummock, } \\
\text { barchanwith } \\
\text { deflation } \\
\text { basins }\end{array}$ \\
\hline $\begin{array}{l}\text { 7.Degradation } \\
\text { degree, } \%\end{array}$ & 0 & $0-5$ & $5-20$ & $20-50$ & More than 50 \\
\hline
\end{tabular}


the slopes -Leymusracemosus is replaced by Artemisia arenaria, the fragments of steppe vegetation are formed in the interbarchan degradations - Stipasareptana - Agropyron fragile - Artemisia lerchiana, the projective cover of which has increased to $60-70 \%$. The sand enrichment with heavy clay fraction is generated by Carexstenophylla.

For the purpose of chernozemic pastures watering, in 1982 the Chernozemelsky collector relating to Chernozemelsky-watering irrigation system (CHOOS) was built. It goes along the southwestern border of the reserve. The studies were conducted on regular profiles in 1990, 2000 and 2010, and showed that in the first year of observations the Phragmites australis, ephemera, annuals were dominating in plant communities canalside zone, in 2000 Phragmites australis became a full dominate. The projective coverage in the zone of $0-2 \mathrm{~m}$ ranged from 40 to $90 \%$, the species composition of monocarpic plants dropped to 4 species, in 2010 - to 1 species (Xanthium strumarium). The width of the meadow zone increased to $10-15 \mathrm{~m}$ with the dominance of Elytrigiaelangatum, E. repens, Calamagrostisepigeios, the subdominants were the mesophilic forbs (Inulabritannica, Lythrumvirgatum, etc.).The formation of the zonal vegetation in the profile is observed in the zone of $15-25 \mathrm{~m}$ from the canal, with a gradual increase of Carexstenophylla, Agropyronpectinatum, A. fragile, Artemisia austriaca, Aarenaria, Stipasareptana. The sods Leymusracemosusare the relic of deflation processes ${ }^{16}$.

Consequently, despite the episodic occurrence of its filling with water in the canalside area, the succession is traced from hygrophytic reed beds to steppificated meadows through quackgrass halophytic and glycophytic options, on the sands - from blady grass communities to sandy steppe.

\section{CONCLUSIONS}

1. On the European continent, the North-West Caspian Sea area is a regional ecotone landscape forming a transition zone between the desert and steppe natural zones.

2. The developed biological concept and research methods determine the vegetation, ecology and time series as indicators of natural and anthropogenic desertification.

3. The mechanism of pasture digression has been determined. We called the change of the community dominants with determinants as the "shift unification". The penetration of new species and their attainment of a dominant position in the community - "incorporation unification".

4. The reversibility of desertification processes has beenestablished. The ecosystem in a strong and very strong degradation can be restored under favorable climatic conditions, reduction of the anthropogenic load to form a single dynamic system.

\section{Credits}

This article was prepared under a grant from the Russian Foundation for Basic ResearchNo. 14-05-00702.

The authors are grateful to Academician N.G. Kharin for consultations upon material collection, and revere his memory.

\section{REFERENCES}

1. CCD: United Nations Convetion to combat desertification in those countries experiencing serious drought and desertification, particulary in Africa, Geneva. Switzerland, 1994; 71.

2. Kepner, W.G., J.L. Rubio and F. Pedrazzini, Desertification in the Mediterranean Region. Springer, Dordrecht, 2003; 3-9.

3. Ci, Y., Desertification and its control in China. Springer, Germany, 2010.

4. Heshmati, G.A. and V. Squires, Combating Desertification in Asia, Africa and the Middle East. Springer, Dordrecht, 2013.

5. Assessment Report on climate change and its consequences on the territory of the Russian Federation, Vol. I, İoscow: Rosgidromet, 2008; 89.

6. Desertification of Russian Drylands, Ìoscow: KMK, 2009; 289.

7. Bananova, V.A., Map “Anthropogenic desertification of the Kalmyk Autonomous Soviet Socialist Republic”, scale 1:500,000. Novocherkassk: LF VISHAGI, 1989.

8. General Scheme to Combat Desertification of Black Lands and Kizlyar pastures», Rostovon-Don: YuzhGirozem, 1986; 261.

9. Glazovskiy, N.F. and E.B. Gabunschina, Action Programme to combat desertification in 
Kalmykia”. Arid Ecosystems, 1996; 2(2-3): 103109.

10. Rangeland Desertification. Series: Advances in Vegetation Science, Arnalds, O. and S. Archer (Eds.), X, 2000; 19: 209.

11. Climate and Land Degradation, Sivakumar, M.V.K. and N. Ndiang'ui (Eds.), 2007; 26: 623.

12. The Future of Drylands. Proceedings of the International Scientific Conference on Desertification and Drylands Research - Tunis, Tunisia, 19-21 June 2006.

13. Land Degradation and Desertification: Assessment, Mitigation and Remediation, Springer Netherlands, 2010.

14. İÅÀ: Millennium Ecosystem Assessment, Ecosystems and human well-being: Synthesis. Washington DC: Island Press, 2005; 137.

15. Kharin, N.G., N.T. Nechaeva, A.G. Babaev et al., Methodical bases of studying and mapping of desertification processes (based on arid areas of Turkmenistan). Ashgabat: Ylym, 1983; 116.

16. Bananova, V.A. and V.G. Lazareva, rends in the botanical diversity change under the influence of desertification in Kalmykia. Arid Ecosystems, 2014; 2(59): 87-96.

17. Borlikov, G.M., N.G. Kharin, V.A. Bananova and R. Tataishi, Desertification of Caspian Region Drylands (Appendix: 3 maps, scale 1:1,000,000 and 1:2,500,000). Rostov-on-Don: SCNC, 2000; 97.

18. Zolotokrylin, A.N. and V.V. Vinogradova, The relationship between climatic and anthropogenic factors of European Russia southeast revegetation. Arid Ecosystems, 2007; 14: 33-34: 20-33.

19. Lazareva, V.G., V.A. Bananova, V.V. Razumovand A.P. Pritvorov, Cartographic mapping of lands desertification in southern Russia. Geodesy and Cartography, 2007; 10: 36-41.

20. Lazareva, V.G. and V.A. Bananova, Dynamics of anthropogenic desertification in the arid landscapes of Kalmykia. Elista: KalmGu, 2014; 72. 